\title{
PENGARUH PENGGUNAAN EKSTRAK DAUN TEH HIJAU (Camellia sinensis) PADA PROSES PEMBUATAN NAGET DAGING SAPI TERHADAP SIFAT KIMIA
}

\section{THE EFFECT OF USING GREEN TEA EXTRACT (Camellia sinensis) ON BEEF NUGGETS MAKING PROCESS TOWARDS CHEMICAL PROPERTIES}

\begin{abstract}
Green tea is known as a plant who has many purpose as well as an antioxidant sources. The purpose of this research is to find out the effect of adding green tea (Camellia sinensis) extract in beef nuggets on chemical properties (moisture content, fat content, and polyphenol content). This research is an experimental research using completely randomized design method with 4 treatments and 5 repetition. The treatment that given was $\mathrm{P} 1=$ beef nugget with no added green tea extract, $\mathrm{P} 2=$ beef nugget $+0,5 \%$ green tea extract, $\mathrm{P} 3=$ beef nugget $+1 \%$ green tea extract, and $\mathrm{P} 4=$ beef nugget $+1,5 \%$ green tea extract with 5 repetition. Chemical analysis that used in this research is moisture content analysis, fat content, and polyphenols content. The obtained results then tested with anova, duncan, and polynomial test. The results showed that the treatment had a significantly real effect on polyphenols content but not on the moisture content and fat content. The addition of $1,5 \%$ green tea (Camellia sinensis) extract increase the polyphenol content of $305,96 \mathrm{mg} / \mathrm{kg}$ and influence $80,79 \%$ of the polyphenol content.
\end{abstract}

Keywords: Beef nuggets, fat, green tea, moisture, polyphenols.

\section{Sitasi:}

Maulana, M. F., Suryaningsih, L., \& Pratama, A. (2020). Pengaruh Penggunaan Ekstrak Daun Teh Hijau (Camellia sinensis) pada Proses Pembuatan Naget Daging Sapi terhadap Sifat Kimia. Jurnal Teknologi Hasil Peternakan, 1(1):34-40.

\section{PENDAHULUAN}

Daging sapi merupakan sumber protein yang diminati karena memiliki banyak kandungan gizi yang bermanfaat bagi tubuh. Daging sapi merupakan salah satu bahan pangan yang dapat dikonsumsi atau diolah dengan berbagai cara seperti dipanggang dan direbus, akan tetapi tidak semua potongan daging menjadi pilihan utama bagi para pelanggan. Salah satu potongan daging tersebut adalah flank yang dianggap terlalu banyak lemak sehing- ga harga potongannya lebih murah dibanding yang lain sehingga perlu dilakukan proses pengolahan agar meningkatkan minat pelanggan. Olahan daging yang digemari oleh pelanggan adalah naget.

Naget merupakan salah satu olahan berbahan dasar daging yang dicampur dengan bahan lain seperti tepung dan bumbu bumbu lainnya. Tidak banyak naget yang dibuat dari daging sapi, namun, dalam pembuatan naget dapat digunakan juga daging 
sapi yang kualitas rendah sehingga biaya produksi naget pun dapat ditekan. Daging sapi yang berharga murah ini biasanya mengandung banyak lemak sehingga mempengaruhi sifat sifat kimia dari produk naget nantinya seperti kadar lemak, dan air. Penambahan antioksidan alami dapat memperpanjang masa simpan dan daya awet dari suatu produk pangan, dan salah satu antioksidan alami tersebut terdapat dalam teh hijau (Bozkurt, 2006).

Penggunaan antioksidan alami mulai mendapat perhatian dari masyarakat karena memiliki dampak yang kecil dibanding antioksidan sintetis. Kandungan polifenol dalam teh merupakan salah satu antioksidan alami yang bagus dan bermanfaat juga bagi kesehatan manusia seperti antikanker, antidiabetes, dan anti penyakit degeneratif lainnya (Rohdiana, 2015; Rietveld et al., 2003).

Penelitian ini bertujuan untuk mengetahui pengaruh pemberian ekstrak daun teh hijau (Camellia sinensis) terhadap sifat kimia (kadar air, kadar lemak, dan kadar polifenol) naget daging sapi, konsentrasi penggunaan ekstrak daun teh hijau (Camellia sinensis) terbaik terhadap sifat kimia naget daging sapi, dan mengetahui respon yang diberikan (sifat kimia) dari setiap perlakuan yang berbeda beda.

\section{MATERI DAN METODE}

\section{Bahan Penelitian}

Bahan dalam penelitian ini terbagi menjadi bahan pembuatan naget dan bahan analisis kimia. Bahan pembuatan naget sendiri adalah daging sapi flank (200 gram per adonan), Teh hijau (P1 sebesar 0\%, P2 sebesar 0,5\%, P3 sebesar1\%, dan P4 sebesar 1,5\% dari berat daging sapi dalam adonan), tepung terigu ( $10 \%$ dari berat daging), telur ayam (2 sendok makan), susu bubuk (6\% dari berat daging), dan bumbu bumbu (Bawang putih 2\%, lada bubuk 1\% dan garam 2\% dari berat adonan). Bahan analisis kimia sendiri terdiri dari sampel, kloroform, pereaksi
Folin Coelteau 10\%, pereaksi Natrium Karbonat 7,5\%, dan larutan standar asam galat $1000 \mathrm{ppm}$.

\section{Peralatan Penelitian}

Peralatan yang digunakan dalam penelitian ini meliputi oven listrik, timbangan analitik, cawan alumunium, desikator, tang penjepit, 1 set alat sokhlet, oven listrik, kertas saring bebas lemak, hekter, desikator, kuvet, batang pengaduk, labu ukur, pipet, alat spektrofotometri, lap, tabung reaksi, sonikator, dan batang penggerus.

\section{Ekstraksi Daun Teh Hijau}

Daun teh hijau kering sebanyak $20 \mathrm{~g}$ direndam dengan $500 \mathrm{ml}$ air mendidih selama 5 menit. Ektrak daun teh hijau didapatkan melalui proses penyaringan (Bozkurt, 2006). Ekstrak daun teh hijau (Camellia sinensis) yang digunakan sebagai pengawet alami akan ditambahkan pada adonan naget sapi dengan 4 konsentrasi, masing-masing $0 \%, 0,5 \%, 1 \%$, dan $1,5 \%$ dari berat daging.

\section{Pembuatan Naget Sapi}

Pembuatan naget sapi dilakukan dengan cara menggiling daging terlebih dahulu, lalu ditambahkan dengan telur, tepung tapioka dan susu bubuk untuk membentuk adonan. Adonan yang terbentuk kemudian ditambahkan bumbu yang sudah dihaluskan meliputi bawang putih, garam dan lada bubuk, kemudian ditambahkan ekstrak daun teh hijau untuk masing-masing perlakuan sebesar $0 \%, 0,5 \%, 1 \%$, dan $1,5 \%$, lalu aduk hingga merata.

Adonan yang sudah tercampur rata kemudian dimasukan ke loyang, lalu dikukus selama 30 menit dengan suhu $66-82^{\circ} \mathrm{C}$. Adonan yang sudah matang ditiriskan, kemudian dimasukkan dalam lemari pendingin selama \pm 30 menit, lalu dipotong-potong dengan ukuran $1 \times 3 \mathrm{~cm}$ dengan ketebalan 1,5 $\mathrm{cm}$. Naget yang telah dipotong kemudian dilumuri dengan tepung terigu 
dan tepung panir, kemudian produk naget sapi siap untuk dianalisis (Thohari et al., 2017). Formulasi pembuatan naget daging sapi disajikan pada Tabel 1.

\section{Pengujian Kadar Air}

Dilakukan pengujian kadar air untuk mengetahui jumlah air pada produk naget sapi dengan ekstrak daun teh hijau. Penghitungan kadar air dilakukan mengunakan metode analisis kadar air menurut (Sudarmadji et al., 2003).

\section{Pengujian Kadar Lemak}

Dilakukan pengujian kadar lemak untuk mengetahui jumlah lemak pada produk naget sapi dengan ekstrak daun teh hijau. Penghitungan kadar lemak dilakukan mengunakan metode analisis kadar lemak menurut (AOAC, 2005).

\section{Pengujian Kadar Polifenol}

Dilakukan pengujian kadar polifenol untuk mengetahui jumlah polifenol pada produk naget sapi dengan ekstrak daun teh hijau. Penghitungan jumlah polifenol dilakukan mengguna- kan metode analisis polifenol menurut (Ghasemi, et al., 2009).

\section{HASIL DAN PEMBAHASAN}

Rataan pengaruh penggunaan ekstrak daun teh hijau (Camellia sinensis) pada proses pembuatan naget daging sapi terhadap sifat kimia (kadar air, kadar lemak, dan kadar polifenol) disajikan pada Tabel 2.

\section{Kadar Air}

Hasil uji kadar air menunjukkan bahwa penambahan ekstrak teh hijau tidak memberikan pengaruh yang nyata pada kadar air naget daging sapi. Hasil ini bisa disebabkan oleh beberapa faktor. Pertama, kandungan polifenol dalam ekstrak teh hijau cair yang digunakan dan tidak memberikan perbedaan yang nyata pada variabel kadar air. Menurut Do et al., (2014), ekstrak teh hijau memiliki kandungan polifenol sebesar 6,25 $\pm 0,24 \mathrm{mg}$ GAE (Gallic Acid Equivalent)/g, total flavonoid sebesar 4,04 $\pm 0,08$ dengan hasil ekstraksi sebesar 25,58 $\pm 1,04 \%$. Jumlah ini disebabkan karena air bukanlah media ekstraksi terbaik untuk mengekstrak polifenol, sehingga jumlah tersebut tidak cukup besar untuk memberikan perubahan yang nyata pada kadar air.

Tabel 1. Formulasi Produk Naget Sapi

\begin{tabular}{|c|c|c|c|c|}
\hline \multirow{3}{*}{ Bahan } & \multicolumn{4}{|c|}{ Perlakuan } \\
\hline & P1 & P2 & P3 & $\mathrm{P} 4$ \\
\hline & \multicolumn{4}{|c|}{...........gram ............ } \\
\hline Bahan Utama & & & & \\
\hline Daging Sapi (Flank) & 200,00 & 200,00 & 200,00 & 200,00 \\
\hline Ekstrak Teh Hijau & 0,00 & 1,00 & 2,00 & 3,00 \\
\hline \multicolumn{5}{|l|}{ Bahan Tambahan } \\
\hline Tepung Tapioka & 20,00 & 20,00 & 20,00 & 20,00 \\
\hline Telur Ayam & 0,06 & 0,06 & 0,06 & 0,06 \\
\hline Susu Bubuk & 12,00 & 12,00 & 12,00 & 12,00 \\
\hline Total Adonan & 232,06 & 233,06 & 234,06 & 235,06 \\
\hline \multicolumn{5}{|l|}{ Bumbu } \\
\hline Bawang Putih & 4,64 & 4,66 & 4,68 & 4,70 \\
\hline Lada Bubuk & 2,32 & 2,33 & 2,34 & 2,35 \\
\hline Garam & 4,64 & 4,66 & 4,68 & 4,70 \\
\hline Total & 243,66 & 244,71 & 245,76 & 246,81 \\
\hline
\end{tabular}


Tabel 2. Rataan Pengaruh Perlakuan terhadap Sifat Kimia Naget Daging Sapi

\begin{tabular}{lcccc}
\hline \multirow{2}{*}{ Peubah } & \multicolumn{4}{c}{ Perlakuan } \\
\cline { 2 - 5 } & P1 & P2 & P3 & P4 \\
\hline Kadar Air $(\%)$ & 53,19 & 54,37 & 54,26 & 54,01 \\
Kadar Lemak $(\%)$ & 12,24 & 13,70 & 13,30 & 13,23 \\
Kadar Polifenol $(\mathrm{mg} / \mathrm{kg})$ & $233,19^{\mathrm{a}}$ & $255,99^{\mathrm{a}}$ & $253,23^{\mathrm{a}}$ & $305,96^{\mathrm{b}}$ \\
\hline Keterangan: & & & \\
P1 : Pemberian konsentrasi ekstrak teh hijau 0\%. & & & \\
P2 & : Pemberian konsentrasi ekstrak teh hijau 0,5\%. & & \\
P3 & : Pemberian konsentrasi ekstrak teh hijau 1\%. & & & \\
P4 : Pemberian konsentrasi ekstrak teh hijau 1,5\%. & & &
\end{tabular}

Menurut Fu et al., (2017), penambahan ekstrak teh hijau dapat menurunkan kadar air karena teh hijau memiliki senyawa EGCG (Epigallochatechin gallat) dalam polifenol yang membentuk senyawa dimer (monomer yang identik satu sama lain) dalam air. Pembentukan senyawa ini menyebabkan EGCG berikatan dengan air dalam adonan dan mengurangi kandungan air dalam adonan, akan tetapi dengan sedikitnya kadar polifenol pada ekstrak yang ditambahkan maka perubahan kadar air cenderung sama. Kedua, penemuan ini dapat disebabkan oleh perbedaan sifat antara permukaan daging dengan polifenol. Menurut Han et al., (2010), permukaan daging secara general memiliki sifat hidrofobik, sementara menurut Arizka et al., (2015), polifenol sendiri adalah senyawa higroskopis. Perbedaan sifat inilah yang menyebabkan interaksi tidak dapat terjadi. Kadar air naget daging sapi ini masih sesuai dengan standar yang ditetapkan oleh BSN (2014) yang menyatakan bahwa kadar air maksimal pada naget sebesar $60 \%$.

\section{Kadar Lemak}

Hasil uji kadar lemak menunjukkan bahwa penambahan ekstrak teh hijau tidak memberikan pengaruh yang nyata pada kadar lemak naget daging sapi. Penemuan ini bisa disebabkan oleh beberapa sebab. Pertama, penemuan ini dapat disebabkan oleh kandungan polifenol dalam ekstrak teh hijau cair yang digunakan pada penelitian ini. Menurut Do et al., (2014), ekstrak teh hijau cair memiliki kandungan poli- fenol sebesar 6,25 $\pm 0,24 \mathrm{mg}$ GAE (Gallic Acid Equivalent)/g, total flavonoid sebesar 4,04 $\pm 0,08$ dengan hasil ekstraksi sebesar 25,58 $\pm 1,04 \%$. Jumlah tersebut tidak cukup besar untuk memberikan perubahan yang nyata pada kadar lemak. Kedua, perbedaan sifat antara lemak dalam daging dengan sifat polifenol. Menurut deMan et al., (2018), komponen daging seperti lemak sendiri terdiri dari 3 jenis berdasarkan ikatannya, yaitu trigliserida, digliserida, dan monogliserida. Lemak jenis monogliserida, digliserida, trigliserida larut dalam pelarut lemak seperti kloroform, eter, esther, dan pelarut lemak lainnya yang bersifat lipofilik. Menurut Yamaguchi et al., (2017) penambahan air pada ekstrak akan meningkatkan sifat lipofobik pada ekstrak. Ekstrak yang digunakan pada penelitian ini memiliki kandungan air yang banyak, sehingga ekstrak bersifat lipofobik seperti yang diungkapkan Yamaguchi et al., (2017) tadi. Perbedaan sifat antara komponen daging pada naget dan ekstrak teh hijau ini menyebabkan tidak adanya interaksi yang terjadi antara ekstrak teh hijau dengan naget daging sapi, sehingga tidak terjadi perubahan pada kadar lemak. Kadar lemak dalam naget daging sapi ini masih ada dalam taraf yang normal. Menurut BSN (2014), kadar lemak maksimum pada naget adalah $20 \%$.

\section{Kadar Polifenol}

Hasil uji kadar polifenol menunjukkan bahwa penambahan ekstrak teh hijau memberikan pengaruh nyata pada kadar polifenol naget daging sapi. 
Hasil uji jarak berganda duncan menunjukkan bahwa pemberian ekstrak teh hijau pada naget daging sapi dengan konsentrasi 1,5\% (P4) nyata $(\mathrm{P}<0,05)$ dengan kadar polifenol sebesar 305,96 mg/kg dan lebih besar dibandingkan dengan konsentrasi 0\% (P1), 0,5\% (P2), dan 1\% (P3). Hasil ini dapat disebabkan karena pemberian ekstrak teh hijau pada (P4) paling besar diantara lainnya.

Perlakuan P4 yang berbeda nyata ini sesuai dengan penda-pat (Essa et al., 2018) yang menyatakan bahwa penambahan ekstrak biji kurma pada produk burger dengan ekstrak kurma yang mengandung senyawa polifenol sebesar $25 \%$ memberikan pengaruh yang nyata dibandingkan perlakuan kontrol. Hal ini disebabkan semakin tinggi konsentrasi yang diberikan maka kadar polifenol semakin banyak. Kondisi semakin banyaknya kadar polifenol ini juga dipengaruhi oleh persentase bahan penyusun naget per adonan. Bahan penyusun tersebut antara lain adalah lada, bawang putih dan garam yang berbeda beda antar perlakuan. Bahan penyusun seperti garam dan lada dapat mengurangi kadar air, sehingga kadar polifenolnya meningkat (Rodov et al., 2010). Pemberian ekstrak teh hijau pada perlakuan P4 merupakan yang terbesar dan memberikan kinerja yang baik dalam tingkat penambahan yang tertinggi. Peristiwa ini juga disertai dengan interaksi antara bahan penyusun dengan daging yang lebih baik pada konsentrasi tertinggi sehingga perlakuan $\mathrm{P} 4$ berbeda nyata dengan perlakuan lainnya.

Data pada Tabel 2 menunjukkan bahwa kadar polifenol pada konsen- trasi $0 \%(\mathrm{P} 1), 0,5 \%$ (P2), dan 1\% (P3) masing masing tidak berbeda nyata. Penemuan ini sesuai dengan pernyataan dari (Urquaiaga et al., 2018) yang menyatakan pada penelitiannya bahwa tidak ada perbedaan kadar polifenol yang signifikan pada perlakuan kontrol dibandingkan dengan perlakuan yaitu injeksi limbah wine berpolifenol pada burger daging sapi karena pada perlakuan kontrol sendiri sudah terdapat kandungan polifenol yang berasal dari campuran adonan. Dalam penelitian ini, dapat diduga bahwa P1, P2, dan P3 sudah terdapat kadar polifenol kerena polifenol ini berasal dari tepung terigu, bawang putih, dan lada yang ditambahkan dalam adonan tetapi dalam jumlah yang lebih sedikit dibandingkan P4. Perbedaan jumlah ini menyebabkan tidak adanya perubahan yang signifikan dengan P2 dan P3 yang ditambahkan ekstrak teh hijau berpolifenol. (Rodov et al., 2010; Hitmahani et al., 2014; Chen et al., 2014)

Dilakukan juga uji polinomial untuk mengetahui hubungan yang diberikan oleh perlakuan terhadap kadar polifenol. Uji yang telah dilakukan meperoleh hasi pada Ilustrasi 1. Regresi linear dipilih karena nilai signifikansinya lebih kecil daripada $0,05(\mathrm{P}<0,05)$. Terlihat bahwa koefisien determinasi yang diperoleh sebesar 0,8079 dengan persamaan $y=21,554 x+208,21$. Hasil ini memberikan arti bahwa ekstrak teh hijau yang diberikan memberikan pengaruh sebanyak $80,79 \%$ pada kadar polifenol yang dihasilkan. Sisa sebesar $19,21 \%$ merupakan pengaruh yang dapat berasal dari berbagai proses, seperti pada saat pembuatan naget daging sapi dan metode analisis kadar polifenol. 


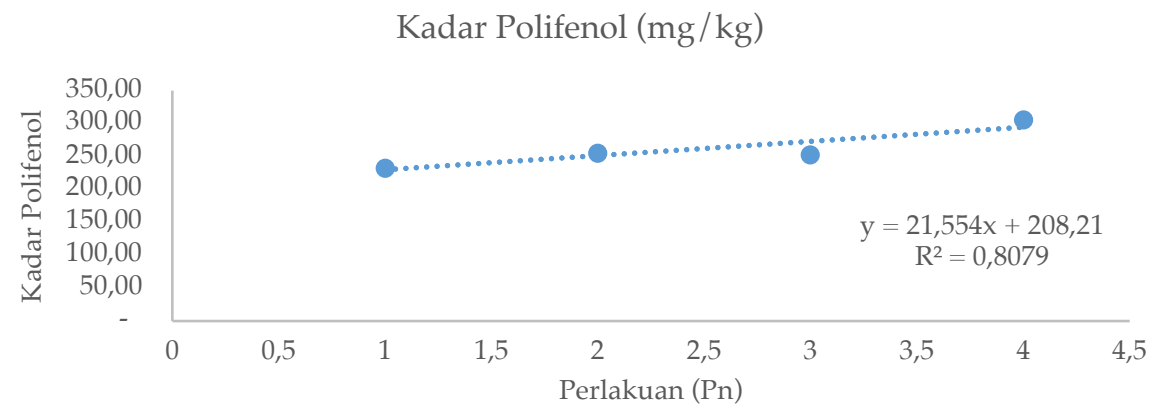

Ilustrasi 1. Kadar Polifenol dalam naget daging sapi.

\section{KESIMPULAN DAN SARAN}

1. Kesimpulan

Pemberian ekstrak teh hijau berpengaruh terhadap kadar air dan kadar lemak, namun dapat meningkatkan kadar polifenol naget daging sapi. Pemberian ekstrak teh hijau sebanyak 1,5\% memberikan nilai terbaik pada kadar polifenol sebesar 305,96 mg/kg. Perlakuan penambahan ekstrak teh hijau memberikan pengaruh sebesar 80,79\% terhadap kadar polifenol dalam naget daging sapi dengan persamaan $\mathrm{y}=$ $21,554 x+208,21$

\section{Saran}

Penambahan ekstrak teh hijau sebesar 1,5\% dapat digunakan dalam pembuatan naget daging sapi karena memberikan peningkatan pada kadar polifenol. Perlu adanya penelitian lebih lanjut untuk meneliti manfaat ekstrak teh hijau dalam bentuk ekstrak yang berbeda, jenis pelarut ekstrak yang berbeda, dan konsentrasi ekstrak yang lebih tinggi. Penggunaan ekstrak teh hijau sebaiknya dipadukan dengan zat antioksidanyang lain karena zat aktif polifenol bekerja sinergis dengan antioksidan lain seperti asam askorbat.

\section{DAFTAR PUSTAKA}

AOAC. (2005). Official Methods of Analysis. Association of Official Analytical Chemists. Benjamin FranklinStation. Washington.

Arizka, A. A. \& Daryatmo, J. (2015). Changes of Water Content and Moisture of Tea during Storage in Different Temperature and Packaging. Jurnal Aplikasi Teknologi Pangan, 4(4):1-6.

Badan Standardisasi Nasional. (2014). SNI. 01-6683. Naget Ayam. Badan Standarisasi Nasional. Jakarta. 1-4.

Bozkurt, H. (2006). Pemanfaatan Antioksidan Alami: Ekstrak Teh Hijau dan Minyak Thymbra Spicata dalam Sosis Turki Kering yang Difermentasi. Meat Science, 73:442-450.

Chen, S., Shen, X., Cheng, S., Li, P., Du, J., Chang, Y., \& Meng, H. (2013). Evaluation of garlic cultivars forpolyphenolic content and antioxidant properties. PloS one, 8(11):e79730.

DeMan, J. M., Finley, J., Hurst, W. J., \& Lee, C. (2018). Principle of Food Chemistry. Springer. United States. 39-116.

Do, Q. D., Angkawijaya, A. E., TranNguyen, Phuong-Lan, Huynh, L. H., Soetaredjo, F. E., Ismadji, S., \& Ju, Y. (2014). Effect of Extraction Solvent on Total Phenol Content, Total Flavonoid Content, and Antioxidant Activity of Limnophila aromatica. Journal of Food and Drug Analysis, 296-302.

Essa, R. Y., \& Elsebaie, E. M. (2018). Effect of Using Date Pits Powder 
as a Fat Replacer and Anti Oxidative Agent on Beef Burger Quality. J. Food and Dairy Sci., 9(2):91-96.

Fu, Z., Yoo, J. Y., Michelle, Zhou, W., Zhang, L., Chen, Y., \& Lu, J. (2017). Effect of (-)-epigabllocatehcin gallate (EGCG) Extracted From Green Tea in Reducing the Formation of Acrylamide During Bread Baking Process. Food Chemistry, 9(50):1-24.

Ghasemi, K., Ghasemi, Y., Ebrahimzadeh, \& Ali, M., (2009). Antioxidant Activity, Phenol, and Flavonoid Contents of 13 Citrus Species Peels and Tissues. Pakistan Journal of Pharmaceutical Science, 22(3):277-281.

Han, J., Britten, Ml., St-Gelais, D., Champagne, C. P., Fustier, P., Salmieri, S., \& Lacroix, M. (2010). Effect of Polyphenolic Ingredients on Physical Characteristics of Cheese. Food Research International, 44:494-497.

Hitmahani, G. \& Srinivasan, K. (2014). Bioaccessibility of Polyphenols From Wheat (Triticum aestivum), Sorghum (Sorghum bicolor), Green Gram (Vigna radiata), and Chick Pea (Cicer arietinum) as Influenced by Domestic Food Processing. I Agric Food Chem, 62(46):11170-9.

Sudarmadji, S., Haryono, B., \& Suhardi. (2003). Prosedur untuk Uji Analisis Makanan dan Pertanian. Liberty. Yogyakarta. 1-160.
Rietveld A. \& Wiseman. S. (2003). Antioxidant Effects of Tea: Evidence from Human Clinical Trials. JNutr., 133:3285-3292.

Rohdiana, D. (2015). Teh: Proses, Karakteristik dan Komponen Fungsionalnya. Food Review Indonesia,10:34-38.

Rodov, V. \& Chkhikvishvili, I. (2010). Hydrophilic and lipophilic antioxidant capacities of Georgian Spices for Meat and Their Possible Health Implications. Georgian Medical News. 1-8.

Thohari, I., Mustakim, M. C. P., \& Premy, P. P. (2017). Teknologi Hasil Ternak. UB Press: Malang.912.

Urquaiga, I., Danitza, T., Maria, J. M., Catalina, U., Druso, P., Sara, D., Paula, M. C., Ludwig, A., Juan, C. C., Guadalupe, E., \& Attilio, R. (2018). The Consumption of Beef Burgers Prepared Wine Grape Pomace Flour Improves Fasting Glucose, Plasma Antioxidant Levels, and Oxidati Damage Markers in Humans: A Controlled Trial. Nutrients, 10(10):e1388.

Yamaguchi, K. K. L., Lamarao, C. V., Aranha, E. S. P., Souza, R. O. S., Oliveira, P. D. A., Vasconcellos, M. C., Lima, E. S., \& VeigaJunior, V. F. (2017). HPLC-DADProfile of Phenolic Compunds, Cytotoxicity, Antioxidant and AntiInflammatory Activities of The Amazon Fruit Caryocar villosum. Quim. Nova 40(5): 1-6. 